\title{
PENGARUH STRATEGI BELAJAR KOGNITIF, METAKOGNITIF DAN SOSIAL AFEKTIF TERHADAP HASIL BELAJAR IPA
}

\author{
N. K. Sri Widyantari, I Nyoman Suardana, N.L Pande Latria Devi \\ Program Studi S1 Pendidikan IPA \\ Universitas Pendidikan Ganesha \\ Singaraja, Indonesia \\ e-mail: kadek.sri.widyantari@undiksha.ac.id,nyoman.suardana@undiksha.ac.id, \\ latria.devi@undiksha.ac.id
}

\begin{abstract}
Abstrak
Penelitian ini bertujuan menganalisis pengaruh strategi belajar kognitif, metakognitif dan sosial afektif terhadap hasil belajar IPA. Jenis penelitian adalah ex post facto yang bersifat korelasional. Populasi penelitian adalah seluruh siswa kelas VIII SMP Negeri se-Kecamatan Tegallalang Tahun Pelajaran 2018/2019 yang berjumlah 943 siswa. Sampel penelitian berjumlah 273 siswa yang diambil dengan teknik proporsional random sampling. Data hasil belajar IPA dikumpulkan menggunakan metode tes dan data strategi belajar kognitif, metakognitif dan sosial afektif dikumpulkan dengan metode kuesioner. Analisis data menggunakan uji regresi linier sederhana dengan taraf signifikansi 0,05 . Hasil penelitian ini menunjukan bahwa 1) terdapat hubungan yang positif dan signifikan antara strategi belajar kognitif dan hasil belajar IPA dengan koefisien korelasi sebesar 0,42 kategori sedang, 2) terdapat hubungan yang positif dan signifikan antara strategi belajar metakognitif dan hasil belajar IPA dengan koefisien korelasi sebesar 0,22 kategori lemah dan 3) terdapat hubungan yang positif dan signifikan antara strategi belajar sosial afektif dan hasil belajar IPA dengan koefisien korelasi sebesar 0,18 kategori sangat lemah.
\end{abstract}

Kata kunci: strategi belajar kognitif, metakognitif, sosial afektif, hasil belajar IPA

\begin{abstract}
This research aims to analyze the effect of cognitive, metacognitive and social affective learning strategies on science learning outcomes. This type of research is ex post facto which is correlational. The study population was all eighth grade students Middle School in Tegallalang District 2018/2019 Academic Year for total 943 students. The research sample up to 273 students taken by proportional random sampling technique. Science learning outcomes data were collected using a test method and data are affective cognitive, metacognitive and social learning strategies were collected by questionnaire method. Data analysis using a simple linear regression test with a significance level of 0.05 . The results of this study indicate that 1 ) there is a positive and significant relationship between cognitive learning strategies and science learning outcomes with a correlation coefficient of 0.42 moderate categories, 2) there is a positive and significant relationship between metacognitive learning strategies and science learning outcomes with correlation coefficients for 0.22 weak categories and 3 ) there is a positive and significant relationship between affective social learning strategies and science learning outcomes with a correlation coefficient of 0.12 categories very weak.
\end{abstract}

Keywords: cognitive, metacognitive, social affective learning strategies, science learning outcomes

\section{PENDAHULUAN}

Hasil belajar merupakan salah satu bagian terpenting dalam pembelajaran mencakup pengetahuan (knowledge), sikap (attitude) dan keterampilan (skills). Hasil belajar adalah kemampuan yang dimiliki siswa setelah menerima pengalaman belajarnya (Sudjana, 2010). Keberhasilan siswa dalam pembelajaran dapat dilihat dari hasil belajar yang dicapai. Salah satu indikator tercapai atau tidaknya proses pembelajaran adalah dengan melihat hasil belajar yang dicapai siswa (Anni, 2004).

Pencapaian hasil belajar siswa dalam pembelajaran dipengeruhi oleh faktor 
internal dan faktor eksternal. Faktor internal merupakan segala sesuatu yang melekat pada diri siswa meliputi intelektual, psikologis dan biologis. Salah satu faktor internal aspek psikologis yaitu strategi belajar (learning strategy). Strategi belajar merupakan pikiran atau perilaku yang digunakan oleh siswa dalam memengaruhi hal-hal yang dipelajari termasuk memori dan metakognitif. Michael Pressly (dalam Nur, 2000) menyatakan bahwa strategi-strategi belajar adalah operator-operator kognitif meliputi dan terdiri atas proses-proses yang secara langsung terlibat dalam menyelesaikan suatu tugas (belajar). Strategi belajar (learning strategies) adalah upaya yang dilakukan siswa dalam belajar untuk memahami, menggunakan dan mengolah informasi secara individu (Kafadar, 2013). Strategi belajar yang dapat digunakan dan dibelajarkan menurut O'Malley dan Chamot, (1995) yaitu strategi belajar kognitif, metakognitif dan sosial afektif.

Strategi belajar merupkan hal yang penting bagi siswa dalam pembelajaran. Norman (dalam Nur, 2000) tentang pentingnya strategi belajar menyatakan bahwa keberhasilan sebagaian besar siswa bergantung pada kemahiran untuk belajar secara mandiri dan memonitor belajar mereka sendiri. Perbedaan strategi belajar yang digunakan menunjukkan cara tercepat dan terbaik bagi siswa dalam upaya menerima sebuah informasi untuk meningkatkan efektivitas dalam belajar. Analisis pembelajaran menggunakan strategi belajar yang pernah dilakukan sebelumnya terbatas pada pengaruh strategi belajar secara umum sehingga belum dijelaskan kontribusi strategi belajar kognitif, metakognitif dan sosial afektif terhadap hasil belajar.

Strategi belajar kognitif melibatkan transformasi dan manipulasi materi yang sedang dipelajari. Stategi belajar kognitif meliputi tiga aspek sebagai berikut. 1) Mengulang membantu mempertahankan informasi dalam memori jangka pendek. 2) Elaborasi merupakan penambahan rincian informasi baru sehingga informasi yang dibangun menjadi lebih bermakna. 3) Strategi organisasi adalah peningkatan kebermaknaan informasi baru melalui penggunaan struktur-struktur-struktur pengorganisasian. Strategi belajar kognitif membantu siswa dalam mengkonstruksi pengetahuannya sendiri.

Strategi belajar metakognitif adalah pengetahuan siswa tentang belajrnya sendiri atau pengetahuan tentang bagaimana belajar. Stategi belajar metakognitif meliputi tiga aspek sebagai berikut. 1) Perencanaan mencakup penentuan tujuan belajar, sumber-sumber belajar dan refleksi hasil belajar. 2) Monitoring yaitu pemusatan perhatian pada aktivitas belajar yang dilakukan. 3) Regulasi merupakan proses siswa untuk memantau kegiatan belajarnya berdasarkan acuan atau kreteria yang telah ditetapkan. Metakognisi dapat membantu siswa menentukan hal-hal yang dibutuhkan dan menggunakannya untuk mencapai hasil belajar sehingga metakognisi dapat menentukan pencapaian hasil belajar siswa (Kulze dalam Zulyanty, 2017).

Strategi belajar sosial afektif merupakan strategi belajar yang melibatkan siswa belajar dengan orang lain. Strategi belajar sosial afektif erat kaitannya dengan perasaan dan perilaku siswa dalam belajar. Strategi belajar sosial afektif meliputi tiga aspek sebagai berikut. 1) Kerjasama merupakan interaksi yang terjadi antara siswa dengan orang lain untuk mencapai tujuan belajar. 2) Respon sikap merupakan reaksi yang diberikan siswa atas suatu tindakan tertentu. 3) Kontrol emosi merupakan kemampuan pengaturan pada perasaan-perasaan yang timbul dalam pembelajaran. Pembelajaran menekankan aspek sosial yaitu interakasi, pemberian bantuan dan pemberian tanggung jawab pada siswa untuk menyelesaikan tugastugas belajar (Trianto, 2009).

Berdasarkan kajian konseptual yang telah diuraikan, perlu dilakukan penelitian lebih lanjut tentang pengaruh strategi belajar kognitif, metkognitif dan sosial afektif terhadap hasil belajar IPA.

\section{METODE}

Penelitian ini adalah penelitia ex post facto dengan jenis korelasional. Populasi penelitian adalah seluruh siswa kelas VIII SMP Negeri se-Kecamatan Tegallalang tahun pelajaran 2018/2019 yang berjumlah 943 siswa dan terdistribusi ke dalam empat 
sekolah. Pengambilan sampel dilakukan dengan teknik proporsional random sampling.

Data hasil belajar IPA dikumpulkan menggunakan metode tes dengan bentuk tes pilihan ganda. Tes ini digunakan untuk mengukur hasil belajar IPA.Tes hasil belajar IPA berjumlah 30 butir. Karakteristik tes ini adalah memiliki reliabilitas 0,79 kualifikasi tinggi, valid, memiliki daya pembeda lebih besar 0,40 dengan kualifikasi sedang, tinggi dan sangat tinggi serta memiliki tingkat kesukaran tes lebih besar dari 0,20 kualifikasi mudah, sedang dan sukar. Data strategi belajar kognitif, metakognitif dan sosial afektif dikumpulkan dengan menggunakan metode kuesioner. Kuesioner strategi belajar sebanyak 37 pernyataan yang memenuhi kreteria. Karakteristik kuesioner dalam penelitian ini adalah valid

\section{HASIL DAN PEMBAHASAN}

Secara umum hasil penelitian yang dideskripsikan yaitu nilai rata-rata strategi belajar kognitif, metakognitif, sosial afektif, hasil belajar IPA, pengujian asumsi dan pengujian hipotesis. dan memiliki reliabilitas 0,73 berkualifikasi tinggi.

Analisis data penelitian menggunakan analisis deskriptif dan analisis inferensial. Analisis deskriptif digunakan untuk mendeskripsikan nilai rata-rata strategi belajar kognitif, metakognitif, sosial afektif dan hasil belajar IPA. Nilai hasil belajar IPA siswa dikualifikasikan dengan Penilaian Acuan Patokan (PAP). Nilai strategi belajar dikonversi ke skala seratus kemudian dikualifikasikan berdasarkan mean ideal (Mi) dan standar deviasi ideal (Sdi).

Analisis inferensial digunakan untuk menguji hipotesis. Uji hipotesis penelitian menggunakan regresi linier sederhana dengan taraf signifikansi 0,05 . Sebelum pengujian hipotesis dilakukan uji asumsi meliputi uji normalitas, linieritas dan keberartian arah regresi serta uji multikolinieritas.

Perbandingan nilai rata-rata strategi belajar kognitif, metakognitif, sosial afektif dan hasil belajar IPA disajikan pada Tabel 1.

Tabel 1. Perbandingan nilai rata-rata strategi belajar dan hasil belajar IPA

\begin{tabular}{|c|c|c|c|c|}
\hline Statistik & Kognitif & $\begin{array}{l}\text { Strategi Belajar } \\
\text { Metakognitif }\end{array}$ & $\begin{array}{l}\text { Sosial } \\
\text { Afektif }\end{array}$ & $\begin{array}{c}\text { Hasil Belajar } \\
\text { IPA }\end{array}$ \\
\hline Mean & 72,70 & 71,32 & 67,51 & 71,47 \\
\hline Standar Deviasi & 8,05 & 8,10 & 7,35 & 10,52 \\
\hline
\end{tabular}

Berdasarkan Tabel 1 perbandingan nilai rata-rata antara strategi belajar kognitif dan metakognitif tidak jauh berbeda sedangkan nilai rata-rata strategi belajar sosial afektif lebih rendah daripada nilai strategi belajar kognitif dan metakognitif. Hal tersebut mengindikasikan bahwa dalam belajar siswa cenderung menggunakan strategi belajar kognitif dan metakognitif dibandingkan strategi belajar sosial afektif. Nilai rata-rata hasil belajar IPA siswa secara umum yang menggunakan strategi belajar kognitif, metakognitif dan sosial afektif berada pada kategori sedang. Secara lebih rinci strategi belajar kognitif, metakognitif dan sosial afektif disajikan berdasarkan nilai per dimensi. Perbandingan nilai per dimensi strategi belajar kognitif, metakognitif dan sosial afektif disajikan pada Gambar 1.

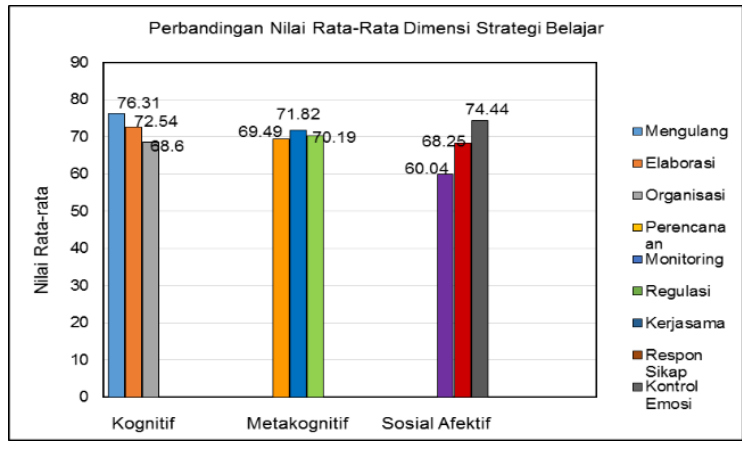

Gambar 1. Perbandingan nilai per dimensi strategi belajar 
Dimensi mengulang pada strategi belajar kognitif memiliki nilai rata-rata paling tinggi daripada elaborasi dan organisasi. Hal tersebut mengindikasikan bahwa siswa yang menggunakan strategi belajar kognitif cenderung pada dimensi mengulang atau membaca materi secara berulang-ulang. Berdasarkan kualifikasi nilai per dimensi strategi belajar kognitif berada pada kualifikasi tinggi.

Dimensi monitoring pada strategi belajar metakognitif memiliki nilai rata-rata paling tinggi daripada dimensi regulasi dan perencanaan. Hal tersebut mengindikasikan bahwa strategi belajar metakognitif yang digunakan siswa cenderung pada dimensi monitoring aktivitas belajar. Berdasarkan nilai per dimensi strategi belajar metakognitif berada pada kualifikasi tinggi.
Dimensi kontrol emosi pada strategi belajar sosial afektif memiliki rata-rata paling tinggi daripada dimensi kerjasama dan respon sikap. Hal tersebut mengindikasikan bahwa strategi belajar sosial afektif yang digunakan siswa cenderung pada dimensi kontrol emosi. Kualifikasi strategi belajar sosial afektif berdasarkan nilai per dimensi memiliki kualifikasi tinggi.

Hipotesis penelitian diuji menggunakan uji regresi linier sederhana. Selain uji regresi juga dilakukan analisis untuk menentukan sumangan efektif dan relatif dari variabel strategi belajar kognitif, metakognitif dan sosial afektif terhadap hasil belajar. Ringkasan hasil analisis regresi secara lengkap disajikan pada Tabel 2.

Tabel 2. Hasil Uji Regresi Linier Sederhana

\begin{tabular}{llccccc}
\hline \multicolumn{1}{c}{$\begin{array}{c}\text { Pasangan } \\
\text { Variabel }\end{array}$} & Persamaan Regresi & Sig. & $\mathbf{r}$ & $\mathbf{R}^{\mathbf{2}}$ & (SE) \% & (SR) \% \\
$\mathrm{X}_{1} \rightarrow \mathrm{Y}$ & $\dot{Y}=33,03+0,52 \mathrm{X}_{1}$ & 0,00 & 0,42 & 0,16 & 15,03 & 82,1 \\
$\mathrm{X}_{2} \rightarrow \mathrm{Y}$ & $\dot{Y}=51,07+0,28 \mathrm{X}_{2}$ & 0,00 & 0,22 & 0,05 & 1,72 & 9,4 \\
$\mathrm{X}_{3} \rightarrow \mathrm{Y}$ & $\dot{Y}=53,57+0,26 \mathrm{X}_{3}$ & 0,02 & 0,18 & 0,03 & 1,59 & 8,7 \\
$\mathrm{X}_{1}, \mathrm{X}_{2}, \mathrm{X}_{3} \rightarrow \mathrm{Y}$ & $\dot{Y}=20,88+0,48 \mathrm{X}_{1}$ & 0,00 & 0,42 & 0,18 & - & - \\
\hline
\end{tabular}

Berdasarkan hasil analisis, diperoleh angka signifikansi pada pasangan variabel kurang dari 0,05 dengan demikian hal tersebut menunjukan bahwa terdapat hubungan yang positif dan signifikan antara strategi belajar kognitif, metakogniti, sosial afektif dan hasil belajar IPA.

\section{Pembahasan}

Hasil analisis menyatakan bahwa 1) terdapat hubungan yang positif dan signifikan antara strategi belajar kognitif dan hasil belajar IPA, 2) terdapat hubungan yang positif dan signifikan antara strategi belajar metakognitif dan hasil belajar IPA dan 3) terdapat hubungan yang positif dan signifikan antara strategi belajar sosial afektif terhadap hasil belajar IPA.

Strategi belajar kognitif dan hasil belajar IPA secara umum menunjukan hubungan bersifat positif. Hal tersebut berarti bahwa jika strategi belajar kognitif meningkat maka hasil belajar IPA yang dapat dicapai siswa juga meningkat. Hasil penelitian ini juga diperkuat oleh penelitian yang dilakukan Dismore dan Zoellner (2017) yang menyatakan bahwa terdapat hubungan yang positif dan signifikan antara strategi kognitif dan pemrosesan informasi pada simulasi sains.

Strategi belajar kognitif memberikan kontribusi positif terhadap hasil belajar IPA karena pada strategi belajar kognitif terdapat kegiatan mengulang (rehearsel), elaborasi dan organisasi. Kegiatan mengulang terdiri atas mengulang sederhana dan mengulang kompleks. Membaca materi berulang-ulang membantu siswa mengingat, menghafal, dan memahami pengetahuan sehingga mendukung pencapaian hasil belajar kognitif pada jenjang mengingat dan memahami. Hal ini didukung oleh pendapat Nur (2000) menyatakan bahwa membaca berulangulang dilakukan siswa untuk mengingat dan mempertahankan pengetahuan lebih lama berada dalam memori jangka pendek sehingga pengetahuan dapat ditransfer ke memori jangka panjang. 
Kegiatan mengulang yang lebih kompleks dilakukan siswa dengan memberikan tanda khusus pada ide-ide kunci materi dan membuat catatan-catatan kecil. Memberikan tanda khusus seperti menggaris bawahi konsep-konsep penting membantu siswa memberikan penekanan pada konsep-konsep penting materi yang dipeljari sedangkan membuat catatan kecil membantu melengkapi pemberian tanda khusus dengan menambahkan catatancatatan kecil pada bagian materi yang digaris bawahi. Selain itu kegiatan ini juga membantu siswa melakukan pengulangan dan penghafalan dengan lebih cepat dan efisien. Anderson dan Armbuster (dalam Nur, 2000) menyatakan bahwa membuat catatan atau note taking efektif diguakan pada materi yang bersifat konseptual dimana tugas yang penting adalah mengidentifikasi ide-ide utama.

Penambahan rincian pengatahuan menjadi lebih bermakna dilakukan melalui kegiatan elaborasi. Kegiatan elaborasi membantu siswa mencapai hasil belajar kognitif pada jenjang menerapkan, menganalisis dan mengevaluasi. Siswa secara individu berlatih menerapkan konsep yang telah mereka peroleh sebelumnya untuk melatih keterampilan berpikir dalam menyelesaikan suatu permasalahan (Adnyani, 2019).

Elaborasi melibatkan aktivitas berpikir yang lebih kompleks diantaranya yaitu mencatat, merangkum isi pelajaran dan membuat analogi-analogi. Kegiatan mencatat membantu siswa meningkatkan keaktifan belajar, kemampuan mengingat informasi, meningkatkan pemahaman materi, memudahkan mempelajari informasi secara singkat dan mengorganisasikan pengetahuan yang telah dimiliki dengan pengetahuan sebelumnya. Hal ini didukung oleh pendapat Sukirman (2004) yang menyatakan bahwa kegiatan mencatat merupakan salah satu aspek penting dalam proses belajar karena kegiatan pembelajaran membantu siswa dalam pengulangan, mengingat, dan mengerjakan tugas-tugas sehingga siswa mendapatkan hasil belajar yang optimal. Hal senada juga diungkapkan Irsyad (2004) yang menyatakan bahwa kegiatan mencatat merupakan proses dimana siswa mencoba memahami materi pelajaran dengan pemahamannya sendiri yang diungkapkan secara tulisan. Kegiatan mencatat sebagai salah satu aspek penting dalam proses pembelajaran dapat meningkatkan pemahaman tentang materi yang dipelajari mengarah pada pencapaian hasil belajar juga dibuktikan oleh hasil penelitian yang dilakukan oleh Dewi dan Rahayu (2014) yang menyatakan bahwa perilaku siswa mencatat mempunyai hubungan yang positif dan signifikan dengan kemampuan memori pada proses belajar.

Kegiatan merangkum isi pelajaran membantu siswa mengulang kembali materi yang telah dipelajari, memahami inti-inti materi, dan membuat hubungan antar beberapa konsep yang sedang dipelajari sehingga informasi yang dibangun pada struktur kognitif menjadi lebih bermakna. Hal tersebut juga didukung oleh pendapat Wormeli (2005) yang menyatakan bahwa kegiatan merangkum memberikan peningkatan yang besar dalam pengertian dan ingatan jangka panjang dari suatu informasi. Selain merangkum isi pelajaran kegiatan elaborasi siswa yaitu membuat analogi konsep-konsep yang dipelajari. Kegiatan analogi membantu siswa menyederhanakan objek yang dipelajari berdasarkan perbandingan ciri-ciri objek yang dimiliki selain itu kegiatan analogi juga memberikan kesempatan bagi siswa untuk membangun pengetahuan mereka sendiri, melatih kemandirian serta kecakapan berpikir. Hal ini didukung oleh pendapat Podomi dan Jailani (2015) yang menyatakan bahwa analogi sebagai bagian kognisi memberikan kesempatan yang lebih luas kepada siswa untuk menalar dan melatih kemandirian belajar.

Kegiatan peningkatan kebermaknaan informasi pada strategi belajar kognitif dilakukan melalui kegiatan organisasi. Kegiatan pengorganisasian membantu siswa mencapai hasil belajar ranah kognitif pada jenjang menerapkan, menganalisis, mengevaluasi dan mencipta. Kegiatan pengorganisasian dapat dilakukan dengan pengelompokan-pengelompokan ulang konsep atau membagi kedalam sub yang lebih kecil. Kegiatan pengorganisasian materi yang dilakukan siswa berupa outlining atau membuat kerangka garis-garis 
besar materi dan pemetaan konsep. Kegiatan Outlining membantu siswa menyajikan ide-ide utama beserta rincian tiap-tiap sub yang disusun secara hirarki sebagai suatu jaringan pengetahuan yang utuh. Selain itu outlining juga membantu siswa menghubungkan berbagai macam konsep dengan konsep dengan konsep lain. Konsep-konsep yang diorganisasikan secara hirarki memudahkan siswa dalam belajar sehingga dapat meningkatkan kebermaknaan informasi. Hal ini didukung oleh pendapat Patten et al., (dalam Nur, 2000) yang menyatakan bahwa pengorganisasian secara hirarki dimana halhal khusus dikelompokan dibawah topiktopik yang lebih umum membantu peningkatan pemahamam siswa.

Kegiatan pengorganisasian melalui pemetaan konsep memudahkan siswa dalam memahami materi yang dipelajari secara sistematis berdasarkan aturanaturan yang disusun secara peta konsep. Selain itu dengan pembuatan peta konsep membantu siswa menggambarkan, mengklasifikasikan serta menganalisis hubungan antar konsep-konsep yang sedang dipelajari sehingga belajar bermakna dapat berlangsung. Hal ini didukung oleh teori belajar Ausubel (dalam Trianto, 2009) yang menyatakan bahwa belajar bermakna dapat terjadi apabila pengetahuan baru dikaitkan dengan pengetahuan sebelumnya pada struktur kognitif melalui pertolongan peta konsep.

Strategi belajar kognitif dan hasil belajar IPA secara umum menunjukan hubungan pada kategori sedang hal ini disebabkan beberapa hal sebagai berikut. Pertama, terdapat karakteristik siswa dengan strategi belajar kognitif sedang memperoleh nilai hasil belajar yang tinggi dan terdapat beberapa siswa dengan strategi belajar kognitif tinggi memperoleh nilai hasil belajar IPA yang rendah. Kedua, kegiatan-kegiatan strategi belajar kognitif belum optimal dilakukan siswa dalam belajar sehingga kontribusi yang diberikan berada pada kategori sedang. Ketiga, dalam belajar siswa tidak hanya menggunakan strategi belajar kognitif akan tetapi siswa juga menggunakan strategi belajar metakognitif dan sosial afektif.
Strategi belajar metakognitif dan hasil belajar IPA secara umum menunjukan hubungan bersifat positif. Hal tersebut berarti bahwa jika strategi belajar metakognitif meningkat maka hasil belajar IPA juga meningkat. Hasil penelitian ini juga diperkuat oleh penelitian yang dilakukan Fauziah et al., (2014) yang menyatakan bahwa terdapat hubungan yang positif dan signifikan antara kemampuan metakognitif dan hasil belajar biologi.

Strategi belajar metakognitif memberikan kontribusi positif terhadap hasil belajar IPA karena pada strategi belajar metakognitif terdapat kegiatan perencanaan aktivitas belajar, refleksi dan regulasi. Kegiatan perencanaan aktivitas belajar melibatkan aktivitas metakognitif membantu siswa mempersiapkan kegiatatan-kegiatan belajar secara sistematis seperti merencanakan waktu belajar, memilih strategi belajar dan menentukan sumbersumber belajar untuk mencapai hasil belajar kognitif. Hal ini didukung oleh pendapat Nur (2000) menyatakan bahwa perencanaan pada aktivitas metakognitif seperti, memperhitungkan waktu belajar dan pemilihan strategi yang efektif membantu siswa dalam belajar dan memecahkan suatu masalah.

Hasil dari kegiatan perencanaan dalam hal ini adalah hasil belajar pada strategi metakognitif direfleksikan pada kegiatan monitoring. Kegiatan refleksi membantu siswa melihat kembali proses belajar yang telah dilalui seperti mengidentifikasi keungulan ataupun kelemahan selama proses belajar sehingga siswa mampu membuat keputusan terhadap hasil belajar yang diperoleh. Zulyanti (2017) menyatakan bahwa kemampuan untuk merefleksikan pengetahuan merupakan metakognisi. Hubungan hasil belajar dengan metakognisi yaitu metakognisi dapat membatu siswa menentukan hal-hal yang dibutuhkan dan menggunakannya untuk mencapai hasil belajar sehingga metakognisi dapat menentukan pencapaian hasil belajar siswa (Kulze dalam Zulyanty, 2017).

Hasil belajar yang dicapai kemudian dibandingan dengan acuan-acuan yang telah ditetapkan dalam belajar melalui kegiatan regulasi. Kegiatan regulasi 
membantu siswa memotivasi diri dalam belajar, mengoptimalkan kemampuankemampuan yang dimiliki, dan menilai proses serta hasil belajar berdasarkan aturan-aturan yang telah mereka tetapkan. Zimmerman dan Schuk (2002) menyatakan regulasi melibatkan proses metakognisi, motivasi dan perilaku dalam belajar. Hubungan regulasi diri dan hasil belajar yaitu regulasi dapat mengelola pikirian, perasaan dan penetapan tindakan yang dilakukan sehingga regulasi mejadi salah satu determinan hasil belajar (Friskilia dan Winata, 2018).

Strategi belajar metakognitif dan hasil belajar IPA secara umum menunjukan tingkat hubungan yang lemah hal ini disebabkan beberapa hal sebagai berikut. Pertama, kegiatan-kegiatan yang melibatkan aktivitas metakognitif seperti perencanaan, monitoring dan regulasi yang dilakukan siswa belum optimal. Kedua, dalam pembelajaran siswa lebih tinggi menggunakan strategi belajar kognitif dibandingkan strategi belajar metakognitif. Ketiga, strategi belajar metakognitif tidak berlaku pada siswa berkemampuan kognitif rendah.

Strategi belajar sosial afektif dan hasil belajar IPA secara umum menunjukan hubungan bersifat positif. Hal tersebut berarti bahwa jika strategi belajar sosial afektif meningkat hasil belajar IPA juga meningkat. Hasil ini juga diperkuat oleh hasil penelitian yang dilakukan Palerangi et al., (2017) yang menyatakan bahwa terdapat pengaruh yang positif dan signifikan antara keterampilan sosial dan kompetensi kejuruan siswa. Strategi belajar sosial afektif memberikan kontribusi positif terhadap hasil belajar IPA karena pada strategi belajar sosial afektif terdapat kegiatan kerjasama, respon sikap dan kontrol emosi. Kegiatan belajar bersama atau kooperatif mendorong siswa berinteraksi dengan pasangan belajar saling bergantung secara positif, saling bertukar ide atau pendapat dan menyatukan persepsi untuk mencapai hasil belajar. Hal ini sejalan dengan teori belajar menurut Vygotsky yang menyatakan bahwa proses belajar akan terjadi secara efektif dan efisien apabila anak belajar secara kooperatif dengan anak-anak lain dalam suasana dan lingkungan yang mendukung, dalam bimbingan orang yang lebih mampu (Masganti, 2017).

Kegiatan respon sikap menunjukan reaksi yang diberika siswa berupa tanggapan atau jawaban atas suatu tindakan tertentu. Kegiatan respon sikap selama pembelajaran memberikan kesempatan bagi siswa untuk bertanya terkait materi dan meminta penjelasan ulang terkait materi yang belum dipahami. Selain itu kegiatan respon sikap juga membantu interaksi aktif antara siswa ataupun siswa dengan guru selama pembelajaran. Selama interaksi guru dapat memberikan penguatan terhadap jawaban siswa, memebrikan masukan atau tambahan serta memberikan penjelasan yang tepat terkait miskonsepsi yang dialami siswa. Hal ini didukung oleh teori belajar Vygotsky yang menyatakan bahwa pembelajaran menekankan aspek sosial yaitu interakasi, pemberian bantuan dan pemberian tanggung jawab pada siswa untuk menyelesaikan tugas-tugas belajar (Trianto, 2009).

Kontrol emosi pada strategi belajar sosial afektif mengarah pada pengaturan pada perasaan-perasaan yang timbul selama pembelajaran. Kegiatan kontrol emosi membantu siswa memotivasi diri dalam belajar, mengatur sikap saat menghadapi tes dan keyakinan terhadap kemampuan diri sendiri untuk menyelesikan tugas-tugas belajar. Goleman (2009) menyatakan bahwa krontrol emosi merupakan salah satu indikator kecerdasan emosional yakni kemampuan mengatasi kegelisahan dalam belajar, motivasi diri, dan pengaturan suasana hati menentukan keberhasilan siswa dalam mencapai prestasi belajar.

Strategi belajar sosial afektif dan hasil belajar IPA secara umum menunjukan hubungan yang sangat lemah hal ini disebabkan beberapa hal sebagai berikut. Pertama, kegiatan-kegiatan pada strategi sosial afektif belum mampu dilakukan siswa dengan optimal untuk meningkatkan hasil belajar. Kedua strategi belajar sosial afektif masih rendah digunakan siswa dalam belajar dibandingan dengan strategi kogntif dan metakognitif. Hal ini menyebabkan strategi belajar sosial afektif memberikan kontribusi yang lebih kecil terhadap hasil belajar dibandingkan strategi belajar kognitif 
dan metakognitif. Ketiga, strategi belajar sosial afektif hanya berlaku pada siswa berkemampuan kognitif sedang dan tinggi

Kontribusi strategi belajar kognitif, metakognitif dan sosial afektif juga ditinjau berdasarkan hasil belajar IPA yang dikelompokkan pada kategori tinggi, sedang dan rendah. Strategi belajar kognitif, metakognitif dan sosial afektif memberikan kontribusi yang positif terhadap hasil belajar tinggi karena siswa berekemampuan kognitif tinggi mempunyai kemampuan berpikir kompleks. Kemampuan berpikir ini membantu siswa mengoptimalkan kegiatankegiatan pada strategi belajar kognitif, metakognitif dan sosial afektif. Hal ini sesuai dengan pendapat Yusuf (2011) yang menyatakan bahwa kemampuan berpikir atau kecerdasan inteligensi mempengaruhi kemampuan belajar, menggunakan pengetahuan dalam rangka memecahkan masalah dan beradaptasi dengan ligkungan. Pribadi siswa terkait intelegensinya memegang peranan besar terhadap tinggirendahnya taraf prestasi belajar siswa, khususnya dalam pelajaran yang menuntut banyak pemikiran misalnya pelajaran sains Winkel (dalam Yusuf, 2011).

Strategi belajar kognitif, metakognitif dan sosial afektif terhadap hasil belajar sedang memberikan kontribusi yang positif karena siswa berkmampuan kognitif sedang mampu melakukan kegiatan-kegiatan belajar kognitif, metakognitif dan sosial afektif untuk mencapai hasil belajar. Hal ini didukung oleh pendapat Sanjaya, (2006) yang menyatakan siswa yang mempunyai kemampuan memadai akan mempengaruhi proses pembelajaran mereka dibandingkan dengsn siswa yang tidak memiliki hal itu. Pada hasil belajar sedang strategi belajar kognitif dan metakognitif memberikan kontribusi yang lebih tinggi dibandingkan strategi belajar sosial afektif.

Strategi belajar kognitif memberikan kontribusi yang bersifat positif terhadap hasil belajar rendah sedangkan strategi belajar metakognitif dan sosial afektif bersifat negatif. Strategi belajar kognitif mampu memberikan kontribusi positif karena siswa berkemampuan rendah dapat melakukan kegiatan-kegiatan mengulang untuk memahami namun belum optimal sehingga hasil belajar yang mampu dicapai berada pada jenjang kognitif yang paling rendah. Siswa berkemampuan rendah ditandai kurangnya motivasi belajar tidak adanya keseriusan dalam belajar dalam menyelesaikan tugas-tugas dan lain sebagainya (Sanjaya, 2006).

Strategi belajar metakognitif berkontribusi negatif terhadap hasil belajar yang berarti jika strategi metakognitif siswa meningkat maka hasil belajar akan turun. Hal ini terjadi karena siswa berkemampuan rendah belum mampu melakukan kegiatankegiatan berpikir kompleks yang melibatkan metakognisi. Strategi belajar sosial afektif juga memberikan kontribusi negatif terhadap hasil belajar yang berarti bahwa jika strategi belajar sosial afektif meningkat maka hasil belajar akan turun. Hal ini terjadi karena siswa belum mampu melakukan kegiatankegiatan strategi sosial afektif dengan optimal seperti belajar bekerjasama, mengendalikan perasaan dan emosi untuk mencapai hasil belajar.

Berdasarkan uraian tersebut diketahui bahwa strategi belajar kognitif telah terbukti memberikan kontribusi positif terhadap hasil belajar IPA secara umum, hasil belajar IPA kategori tinggi, hasil belajar IPA kategori sedang dan hasil belajar IPA kategori rendah. Dilain pihak strategi belajar metakognitif dan sosial afektif hanya memberikan kontribusi positif terhadap hasil belajar IPA secara umum, hasil belajar IPA kategori tinggi dan hasil belajar IPA kategori sedang. Dari ketiga strategi belajar tersebut dapat disimpulkan bahwa strategi belajar kognitif memberikan kontribusi paling tinggi terhadap hasil belajar IPA. Hal ini dikarenakan strategi belajar kognitif mampu digunakan oleh siswa berkemampuan kognitif rendah hingga berkemampuan tinggi sedangkan strategi belajar metakognitif dan sosial afektif hanya berlaku pada siswa berkemampuan kognitif tinggi dan sedang. Selain itu kegiatan-kegiatan strategi belajar kognitif sering dilakukan siswa dalam pembelajaran sehingga mampu mendukung pencapaian hasil belajar kognitif dari jenjang yang paling rendah sampai paling tinggi.

\section{SIMPULAN DAN SARAN}

Mengacu pada rumusan masalah, analisis data dan pembahasan dapat disimpulkan beberapa hal sebagai berikut. 
Pertama, terdapat hubungan yang positif dan signifikan antara strategi belajar kognitif dan hasil belajar IPA. Kedua terdapat hubungan yang positif dan signifikan antara strategi belajar metakognitif dan hasil belajar IPA. Ketiga terdapat hubungan yang positif dan signifikan antara strategi belajar sosial afektif terhadap hasil belajar IPA.

Berdasarkan berbagai temuantemuan pada penelitian maka dapat disarankan beberapa sebagai berikut. Bagi guru bidang studi IPA, disarankan untuk memotivasi dan mendorong siswa belajar mandiri dalam pembelajaran sehingga siswa mampu menggunakan strategi belajar secara lebih aktif dan optimal untuk menyelesaikan tugas-tugas pembelajaran. Guru juga diharapkan lebih memperhatikan dimensi-dimensi pada setiap strategi belajar kognitif, metakognitif dan sosial afektif, terutama organisasi, perencanaan dan kerjasama. Strategi belajar kognitif, metakognitif dan sosial afektif dapat memberikan kontribusi yang lebih tinggi dengan membelajarkan kepada siswa bagaimana cara menggunakan strategi tersebut. Bagi siswa, diharapkan lebih aktif dan termotivasi dalam pembelajaran dengan adanya strategi belajar kognitif, metakognitif dan sosial afektif. Siswa juga diharapkan dapat menggunakan strategi belajar untuk mencapai hasil belajar yang lebih tinggi. Peneliti selanjutnya diharapkan melakukan penelitian lebih lanjut tentang kontribusi strategi belajar kognitif, metakognitif dan sosial afektif terhadap kemampuan yang lain selain hasil belajar dengan menggunakan topik atau materi yang berbeda serta memperhatikan dimensi masing-masing strategi terutama dimensi organisasi pada strategi belajar kognitif, perencanaan pada strategi belajar metakognitif dan kerjasama pada strategi belajar sosial afektif sehingga diketahui kosistensi hasil penelitian ini.

\section{DAFTAR PUSTAKA}

Adnyani, I.G.A.A.W., Pujani, N.M dan Juniartina, P.P. 2019. Pengaruh Model Learning Cycle 7E Terhadap Keterampilan Berpikir Kristis Siswa. Jurnal Pendidikan dan Pembelajaran Sains Indonesia, 1(1): 1-12.

Anni C. T. 2004. Psikologi Belajar. Semarang: IKIP Semarang Press.
Bahri, D.S dan Aswan, Z. 2010. Strategi Belajar Mengajar. Jakarta: Rineka Cipta.

Dewi, P.B dan Rahayu, I. 2014. Perilaku mencatat dan kemampuan memori pada proses belajar. Jurnal Psikologi Udayana, 1(2): 241-250.

Dismore, D.L dan Zoellner, B.P. 2018. The relation between cognitive and metacognitive strategic processing during a science simulation. British Journal of Educational Psychology, 3 (88): 95-117.

Fauziah, D.R., Aloysius, D.C dan Zubaidah. 2018 Hubungan Keterampilan Metakognitif Terhadap Hasil Belajar Biologi Dan Retensi Siswa Keas X dengan Penerapan Strategi Pembelajaran Think Pair Share di SMA Negeri 6 Malang. ResearchGate, 2(1):15.

Friskilia,O.S dan Winata,H. 2018. Regulasi Diri Sebagai Determinan Hasil Belajar Siswa Sekolah Menegah Kejuruan.Jurnal Pendidikan Manajemen Perkantoran, 3 (1):184-191.

Goleman, D. 2009. Emotional Intelligence. Jakarta: Gramedia Pustaka Utama.

Irsyad, D dan Elfi . 2004. Belajar untuk Belajar. Bukit Tinggi: Usaha Ikhlas.

Kafadar, T. dan Tay. B. 2014. Learning Strategies and Learning Style Used By Student in Social Studies. International Journal of Academic Research, 2(2):259264.

Masganti, S. 2017. Perkmbangan Peserta Didik. Medan: Perdana Publishing.

Nur, M. 2000. Teori-Teori Pembelajaran Kognitif. Surabaya: Universitas Negeri Surabaya Pusat Sains dan Matematika Sekolah.

Palerangi, Tuwoao dan Andoko, 2016. Kontribusi Kemandirian Belajar dan Keterampilan Sosial Terhadap Kompetensi Kejuruan Siswa Paket Keahlian Teknik. Jurnal Pendidikan Teori dan Pengembangan, 1 (9):1806-1816.

Sanjaya,W. 2006. Strategi Pembelajaran Berorientasi Standar Proses Pendidikan. Jakarta: Prenamedia Group.

Sukirman,S. 2004. Tuntunan Belajar di Perguruan Tinggi. Jakarta: Pelangi Cendikya.

O'Malley, J. M and Chamot, A.U. 1990. Learning Strategies in Second Language Acquisition. Cambridge Apllied Linguistic. 
Trianto, 2009. Mendesain Pembelajaran Inovatif-Progresif. Jakarta: Kencana Prenanda Media Grup.

Weinstein, C. E. dan Mayer, R. E. 1983. The Teaching Learning Strategies. In. M.C Handbook of research on teaching. Newyork Macmillan.

Wormeli, R. 2005. Meringkas Mata Pelajaran. Jakarta: Penerbit Erlangga.

Zimmerman, dan Schunk. (2002). Self Regulated Learning and Academic Achievment. Mahwah, New Jersey: Erlbaum.

Zulyanty, M. 2017. Metakognisi Siswa Dengan Gaya Belajar Introvert Dalam Memecahkan Masalah Matematika. Jurnal Kajian Pembelajaran Matematika, 1(1): 12-18.

Yusuf, S, L.N dan Sugandhi, N.M. 2013. Perkembangan Peserta Didik. Jakarta: Raja Grafindo Persada. 